\title{
Influences of Earned Value Management on Construction Project's Performance in Yemen
}

\author{
Waled Hakami, M. A. Shameri, Belal R. Aldhubhani
}

\begin{abstract}
Most of projects in developing countries suffer cost overruns, behind the schedule, and bad quality due to improper monitoring and controlling technique. This study investigated the earned value management in Yemen as a monitoring and controlling technique and its relation with the project performance. The both qualitative and quantitative methods were adopted covering unstructured interview and questionnaire. This study conducted both pilot study and pre-test which led to proper instrument used in large-scale survey. Reliability and validity tests applied on the instrument which judged it to be reliable and valid. SPSS IBM 19 analysed the data showing that the Earned value has not understood due to lack of knowledge and wasn't practiced in the site. Consequently, this led to performance failure. To overcome this issue, the academics and practitioners should study and practice earned value management in Yemen particularly, and in developing countries in general.
\end{abstract}

Keywords: Knowledge of EVM, Developing Countries, Small-Scale Survey, Academics.

\section{INTRODUCTION} targeted project within the budget and align with the planned time [1]. So, the most important process that leads to success the projects are schedule and cost control. Therefore, earned value management (EVM) technique is considered the basis of schedule and cost control which can be applied to small and large-scale construction projects, as well plays a role in forecasting [2]. Even though, there are some calling for the engineers in Serbia to practice the EVM which can be used as a warning tool in the early period of project execution; and thus avoiding greater loses in cost, time or scope [3]. In European's construction industry, the EVM was a poor implementation because it hadn't known. Many researchers, who believed in more efforts of academics and practitioners to understand the EVM, are encouraged to conduct their research to assist the dissemination process in European construction industry [4]. Additionally, in Korean construction industry, the EVM was used in 2000 which faced so many problems to apply it. The main problem was

Revised Manuscript Received on October 30, 2020.

* Correspondence Author

Dr. Waled Hakami*, Assistant Professor, Architecture Department, College of Engineering, University of Science \& Technology, Yemen. Email:W_g2006@yahoo.com

Dr. M. A. Shameri, Assistant Professor, Architecture Department, College of Engineering, University of Science \& Technology, Yemen. Email:shameri2010@yahoo.co.uk

Dr. Belal R. Aldhubhani, Assistant Professor, Architecture Department, College of Engineering, University of Science \& Technology, Yemen. Email: belal412@hotmail.com

(C) The Authors. Published by Blue Eyes Intelligence Engineering and Sciences Publication (BEIESP). This is an open access article under the CC BY-NC-ND license (http://creativecommons.org/licenses/by-nc-nd/4.0/)
The most important aim of construction is to finish the

the project control system [5]. With respect to developing countries, the EVM haven't debated through published papers or conferences as well as haven't applied in the construction field. Monitoring and controlling process have been done mostly by coincidence which sometime is true and other is wrong. In Yemen, the same situation is existing. Consequently, the aim of this study is to investigate the EVM and its relationship with performance of projects in Yemeni's construction industry.

\section{EARNED VALUE MANAGEMENT (EVM)}

On the positive side, EVM has many interests of studies which provide a detailed explanation for the EVM such as "Practice Standard for Earned Value Management" [6], Program Analysis Pamphlet [7], "PMBOK 6th edition" [8], and "Earned value analysis: APM guidelines" [9]. Many definitions were obtained for EVM as "Earned value management is a management methodology for integrating scope, schedule, and resources; for objectively measuring project performance and progress; and for forecasting project outcome."[6], another definition by [5] is "Earned Value $(\mathrm{EV})$ is a project control technique used in many countries which provides a quantitative measure for integrating on schedule and cost information. It also evaluates work progress in order to identify potential delay and cost overruns". It can also be defined as "the earned value management is a tool or technique that determines the status of the project's progress and to forecast the final cost and total duration." [10], or "a project management tool that provides significant managerial benefits by identifying project deliverables, tying these outputs to specific group or individual responsibility, and tracking performance over time" [11]. As well, Fleming [12] defined EVM as "a control method for estimating the final cost and schedule of a project and to perform continuous estimation of actual work in a detailed construction Work plan". Equally important, the earned value plays major role in Projects review which expresses the evaluation of past performance and predicts future performance (cost and time) using quantitative metrics indices $[3,13]$ by metric unit such as financial currency (e.g., Dollars, Rials) [14]. It makes easier to the project manager to take the decision $[13,15]$, if the time is out the schedule or the actual cost is over the budget. It isn't important if the plan is perfect, if there is no systematic revision for construction projects in monitoring stage then the plan couldn't be appraised [16]; thus, the EVM enables managers to check the loop of the PDCA cycle [6].

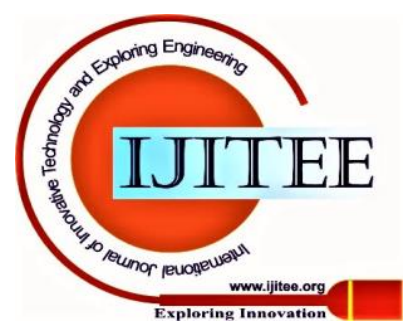




\section{Influences of Earned Value Management on Construction Project's Performance in Yemen}

As well, EVM provides accurately measurements for cost and schedule performances in monitoring and control stage [3], also has satisfactory performance in systematic reporting, resource allocation, and monitoring enhancement [17]. On the other hand, the forecasting can be early when the project at $20 \%$ completes [4], as well, earned value technique can predict the total duration and the final cost within $\pm 10 \%$ when a project at $20 \%$ completes [12]. Furthermore, project managers can measure their finished work and remaining work comparing to the schedule [14], as well, the EV that its concept is integrating schedule with cost [5], gives a whole vision about cost, schedule, the performed work criteria, no indication about quality, human factor, and risk analysis [13].

More importantly, earned value technique helps to avoid litigation between the parties of the project [11], and also can track the small-scale construction projects' performance [3], specifically, tracking schedule, cost; and quality [18]. Additionally, the EVM is considered a tool to measure the indices of performances and answering the following questions:

"Are we delivering more or less work than planned?"

"When is the project likely to be completed?"

"Are we currently over or under budget?"

"What is the remaining work likely to cost?"

"What is the entire project likely to cost?"

"How much will we be over or under budget at the end of the project?"

"What is driving the significant cost and/or schedule variances?" [6].

Moreover, earned value combines budget, schedule, and scope in one direction [14], so, the planning develops the both budget and schedule which make the output of earned value effective [15]. More obviously, the EVM is based on three constraints namely: Budgeted Cost of Work Scheduled (BCWS), Budgeted Cost of Work Performed (BCWP), also known as Earned Value (EV) and Actual Cost of Work Performed (ACWP) as well as the planned budget of the project (Budget at Completion) [3]. In more details, there are three basic variables of EV: planned value (PV) or budgeted cost of work scheduled, actual cost (AC) or the actual cost of work performed, and earned value (EV) or the budgeted cost of work performed. In addition, some measurements can be generated by the following formulas $[6-9,19,20]$ :

Cost Variance: $\mathrm{CV}=\mathrm{EV}-\mathrm{AC}$;

Schedule Variance: SV = EV $-\mathrm{PV}$;

Cost Performance Index: CPI = EV/AC;

Schedule Performance Index: SPI $=\mathrm{EV} / \mathrm{PV}$.

In the first place, the earned value depends on the work breakdown structure (WBS) for both cost and schedule planning [21, 22], and integrates with budget breakdown structure (BBS) or cost breakdown structure (CWB) [12]. The integration between both of them should be in the lowest level of WBS [10]. Project manager should construct WBS providing a basis for construct schedule and process management, for more details refer to [23]. In such researches, the qualitative and quantitative methodology would be used to strengthen the output of this research. It can be seen, the results would be interesting which indicate importance of EVM for Yemeni's construction industry that affected the performance of their projects.

\section{RESEARCH METHODOLOGY}

The research strategy of this study was both the qualitative and quantitative approaches in order to strength this study, so the methodology covered the unstructured interview and questionnaire survey respectively. Firstly, this study is exploratory in its nature; the unstructured interview was the best methods to collect the data about the earned value management in Yemen [24]. Three academics were chose according to their following characteristics in the table (1).

Table 1 Characteristics of experts' academics

\begin{tabular}{|c|c|c|}
\hline No. & Scientific degree & Experience \\
\hline 1 & Professor & 30 years \\
\hline 2 & Assistant professor & 15 \\
\hline 3 & Assistant professor & 12 \\
\hline
\end{tabular}

The three academics experts were asked about the important matters in Yemen regarding to EVM. These three interviews were done separately in the end of 2019, and the outcomes appeared that the three academics agreed to classify the collected data as the following table (2):

Table 2 Suggested variables concerning EVM

\begin{tabular}{|c|c|c|}
\hline Scale & Category & factors \\
\hline \multirow{6}{*}{1} & \multirow{6}{*}{ Knowledge of EVM } & Studying EVM in Bachelor. \\
\hline & & Study WBS \\
\hline & & WBS Dictionary \\
\hline & & Study CBS \\
\hline & & Integrating WBS with CBS \\
\hline & & $\begin{array}{c}\text { Terminologies (EV, CV,SV, } \\
\text { CPI, SPI) }\end{array}$ \\
\hline \multirow{7}{*}{2} & \multirow{7}{*}{$\begin{array}{l}\text { Monitoring and } \\
\text { controlling process }\end{array}$} & Using traditional methods \\
\hline & & Using EVM \\
\hline & & $\begin{array}{c}\text { preparing progress report with } \\
\text { EVM }\end{array}$ \\
\hline & & Determining CV with EVM \\
\hline & & Determining SV with EVM \\
\hline & & $\begin{array}{l}\text { Determining Time Estimate at } \\
\text { Completion with EVM. }\end{array}$ \\
\hline & & $\begin{array}{l}\text { Determining Estimate at } \\
\text { Completion with EVM. }\end{array}$ \\
\hline \multirow{4}{*}{3} & \multirow{4}{*}{ Project performance } & $\begin{array}{l}\text { Ability of monitoring and } \\
\text { controlling }\end{array}$ \\
\hline & & Projects' no delay \\
\hline & & $\begin{array}{l}\text { No Cost overhead than } \\
\text { planned cost }\end{array}$ \\
\hline & & $\begin{array}{l}\text { Ability of determining } \\
\text { increasing in cost and time. }\end{array}$ \\
\hline
\end{tabular}

Furthermore, the academics suggested three hypotheses between the categories in order to discover the relationships between them in Yemeni society. The hypotheses were:

1. Knowledge of EVM has a positive effect on the monitoring and controlling process.

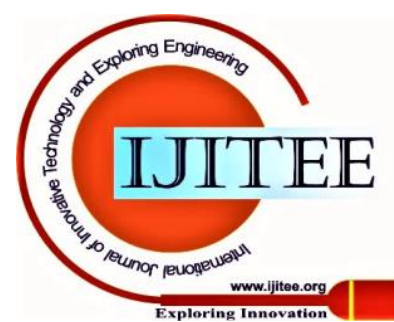


2. Knowledge of EVM has a positive effect on project performance.

3. Applying monitoring and controlling by EVM has a positive effect on project performance.

The author constructed the questionnaire according to the factors that mentioned above, after that the questionnaire were returned to the academics as a pilot study to test the words of the questionnaire in Arabic language. Therefore, they commented on the returned questionnaires, and some modifications were made according to their comments. The Likert's five scale approach was used to scale responses in survey, ranging from "very disagree" to "high agree". In order to be $100 \%$ confidence, the author also conducted a pre-test on small group of academics. So, the feedback helped the author to develop the questionnaire so that the questionnaire was ready for distribution on large scale.

Questionnaires were sent by e-mails and social media (WatsApp, Facebook) to the respondents; the returned questionnaires were 330, which referred to the high response for such researches. The respondents' characteristics showed highly qualifications of experience, and the targeted respondents were architect and civil engineers. This would support the generalization of this study as in table (3) and table (4).

Table 3 Classification of respondents' engineers

\begin{tabular}{|c|c|c|}
\hline Respondents & Frequency & Percentage (\%) \\
\hline Architect & 150 & 45.5 \\
\hline Civil engineer & 180 & 54.5 \\
\hline Total & 330 & 100 \\
\hline
\end{tabular}

Table 4 Experience of respondents

\begin{tabular}{|c|c|c|c|}
\hline $\begin{array}{c}\text { Experience } \\
\text { (year) }\end{array}$ & Frequency & $\begin{array}{c}\text { Percentage } \\
\text { (\%) }\end{array}$ & Remark \\
\hline$<5$ & 90 & 27.3 & \\
\hline$\geq 5<10$ & 90 & 27.3 & \\
\hline$>10$ & 150 & 45.5 & \\
\hline Total & 330 & 100 & \\
\hline
\end{tabular}

In order to analyse the data, the reliability and validity of the instrument should be verified.

\section{A. Reliability}

This study is exploratory research, thus the Cronbach's alpha can't be below the 0.60 [25], in this study's instrument, there were 3 scales in order to measure the knowledge of EVM, applying EVM in monitoring and controlling process, and the performance of implemented projects in Yemen. The SPSS 19 IBM was used to calculate the reliability for the items (questions) of each scale. The scales' reliability coefficients were $0.95,0.94$, and 0.92 respectively, which indicates that the instrument of this study was reliable table (5).
Table 5 Reliability test's results

\begin{tabular}{|c|c|c|}
\hline Scale & No. of items & $\begin{array}{c}\text { Cronbach's } \\
\text { alpha }\end{array}$ \\
\hline 1 & 6 & 0.95 \\
\hline 2 & 7 & 0.94 \\
\hline 3 & 4 & 0.92 \\
\hline
\end{tabular}

\section{B. Item analysis}

Before the factor analysis is done, the item analysis should be done to check the correlation between the items (questions) and its scale. The correlation should be higher than 0.30; those which are lower than 0.30 do not share enough variance with the other items in that scale [26]. It can be seen in table (6), all the items had value greater than 0.30 . Consequently, it was concluded that all items were accepted according to item analysis were appropriately assigned to their scales.

Table 6 Item to scale correlation (Pearson correlation)

\begin{tabular}{|c|c|c|c|}
\hline \multirow{2}{*}{ Item (Question) } & \multicolumn{3}{|c|}{ Scales } \\
\cline { 2 - 4 } & $\mathbf{1}$ & $\mathbf{2}$ & $\mathbf{3}$ \\
\hline 1 & 0.74 & 0.55 & 0.96 \\
\hline 2 & 0.84 & 0.95 & 0.88 \\
\hline 3 & 0.93 & 0.91 & 0.88 \\
\hline 4 & 0.94 & 0.98 & 0.87 \\
\hline 5 & 0.98 & 0.86 & \\
\hline 6 & 0.91 & 0.92 & \\
\hline 7 & & 0.84 & \\
\hline & & & \\
\hline
\end{tabular}

\section{Construct validity}

Of Prime importance, to check the validity of this study's instrument, the exploratory factor analysis was used as a data reduction, because this study was exploratory. In this study, the sample size was 330 and the factor loading should be 0.31 , which was used as the usual cut-off point, as well as the Eigen-value should be greater than or equal to one (Hair et al, 2014). Therefore, SPSS IBM 19 performed the factor analysis to test each scale separately. In table (7), the results of exploratory factor analysis for 3 scales were listed according to No. of factors, Eigen-value, and percentage of variance. Only one factor for each scale had Eigen-value greater than one, so they loaded only on one factor. 
Influences of Earned Value Management on Construction Project's Performance in Yemen

Consequently, there was no needs for using varimax rotate to be check, and there was no reduction of data which indicates that the instrument was valid.

Table 7 Factor analysis test's results

\begin{tabular}{|c|c|c|c|}
\hline Scales & $\begin{array}{c}\text { Factor } \\
\text { Number }\end{array}$ & Eigen-value & $\begin{array}{c}\text { \% of } \\
\text { variance }\end{array}$ \\
\hline \multirow{6}{*}{1} & \multirow{6}{*}{6} & 4.790 & 79.841 \\
\hline & & .771 & 12.851 \\
\hline & & .335 & 5.579 \\
\hline & & .067 & 1.115 \\
\hline & & .033 & .550 \\
\hline & & .004 & .064 \\
\hline \multirow{7}{*}{2} & \multirow{7}{*}{7} & 5.283 & 75.466 \\
\hline & & .746 & 10.654 \\
\hline & & .571 & 8.163 \\
\hline & & .276 & 3.945 \\
\hline & & .081 & 1.162 \\
\hline & & .040 & .576 \\
\hline & & .002 & .033 \\
\hline \multirow{4}{*}{3} & \multirow{4}{*}{4} & 3.224 & 80.594 \\
\hline & & .391 & 9.784 \\
\hline & & .304 & 7.599 \\
\hline & & .081 & 2.023 \\
\hline
\end{tabular}

In this stage, the data were ready to be analyzed in which to extract the results from the fruit of this study.

\section{RESULTS AND DISCUSSION}

After the instrument of this study was reliable and valid, the collected data became ready for analysis. The SPSS IBM 19 analysed the data; the results of analysis are shown in table (8).

Table 8 Results of analysis

\begin{tabular}{|c|c|c|c|c|}
\hline No. & Scale & Factors & Mean & $\begin{array}{c}\text { Scale } \\
\text { mean }\end{array}$ \\
\hline \multirow{2}{*}{1} & $\begin{array}{c}\text { Knowledge } \\
\text { of EVM }\end{array}$ & $\begin{array}{c}\text { Studying EVM } \\
\text { in Bachelor }\end{array}$ & 3.09 & \multirow{2}{*}{3.30} \\
\cline { 3 - 4 } & & Study WBS & 3.27 & \\
\cline { 3 - 4 } & & WBS & 3.45 & \\
\hline
\end{tabular}

\begin{tabular}{|c|c|c|c|c|}
\hline & & Dictionary & & \\
\hline & & study CBS & 3.36 & \\
\hline & & $\begin{array}{c}\text { Integrating } \\
\text { WBS with CBS }\end{array}$ & 3.45 & \\
\hline & & $\begin{array}{c}\text { Terminologies } \\
\text { (EV, CV,SV, } \\
\text { CPI, SPI) }\end{array}$ & 3.18 & \\
\hline \multirow{7}{*}{2} & \multirow{7}{*}{$\begin{array}{l}\text { Applying } \\
\text { EVM in } \\
\text { monitoring } \\
\text { and } \\
\text { controlling } \\
\text { process }\end{array}$} & $\begin{array}{c}\text { Using } \\
\text { traditional } \\
\text { methods }\end{array}$ & 4.72 & \multirow{7}{*}{3.42} \\
\hline & & Using EVM & 3.00 & \\
\hline & & $\begin{array}{c}\text { preparing } \\
\text { progress report } \\
\text { with EVM }\end{array}$ & 3.27 & \\
\hline & & $\begin{array}{l}\text { Determining } \\
\text { CV with EVM }\end{array}$ & 3.00 & \\
\hline & & $\begin{array}{c}\text { Determining SV } \\
\text { with EVM }\end{array}$ & 3.18 & \\
\hline & & $\begin{array}{c}\text { Determining } \\
\text { Time Estimate } \\
\text { at Completion } \\
\text { by EVM }\end{array}$ & 3.27 & \\
\hline & & $\begin{array}{c}\text { Determining } \\
\text { Estimate at } \\
\text { Completion by } \\
\text { EVM }\end{array}$ & 3.54 & \\
\hline \multirow{4}{*}{3} & \multirow{4}{*}{$\begin{array}{c}\text { Project } \\
\text { performance }\end{array}$} & $\begin{array}{c}\text { Ability of } \\
\text { monitoring and } \\
\text { controlling }\end{array}$ & 2.27 & \multirow{4}{*}{2.45} \\
\hline & & $\begin{array}{c}\text { Projects' no } \\
\text { delay }\end{array}$ & 2.72 & \\
\hline & & $\begin{array}{c}\text { No Cost } \\
\text { overhead than } \\
\text { planned cost }\end{array}$ & 2.27 & \\
\hline & & $\begin{array}{c}\text { Ability of } \\
\text { determining } \\
\text { increasing in } \\
\text { cost and time }\end{array}$ & 2.54 & \\
\hline
\end{tabular}

In scale "Knowledge of EVM" the respondents answered the questions concerning the factors which had many different means. 
Therefore, with respect to the factor "Studying EVM in Bachelor" the analysis showed the mean's value of 3.09, which is closed to the mean of average (3), indicates that the respondents may study the earned value management technique in Bachelor program level, in other words, about half of respondents confirm that they study about EVM but the others didn't. This indicator is the worse about the level of high educational level which should be covering the important subjects that the engineers will face in the real life. As well, the factor "Study WBS" had the mean's value of 3.27, which is slightly higher than the mean of average (3), indicates that almost half of respondents haven't known the WBS well. The importance of WBS was confirmed in a case study by [4] in which is considered the base of the EVM which cannot be done without. This result consistent with the previous result which formulating together the whole vision about the situation in Yemen. In addition, the analysis showed the mean's value of 3.45 for the factor "WBS Dictionary", which is slightly higher than the mean of average (3), refers to they may know how to make dictionary for WBS for more than the half of respondents which indicates that this result in the same line with the previous results confirming strongly the gap in the syllabus of construction management in the Universities in public and private sectors. It can be seen that the mean's value of 3.36 for factor "study CBS", is slightly higher than the mean of average (3), which means that the cost breakdown structure haven't fully understood. This technique combines with WBS to formulate the basics of EVM. It is obvious that the Yemeni's engineers haven't studied and understood this technique properly. This definitely affects the future of Yemeni's professional engineers to control and monitor their projects. The field practice may lead to improve the engineers towards this technique if the engineers use their efforts to self-study and practices. Furthermore, the factor "Terminologies (EV, CV, SV, CPI, and SPI)" had the mean's value of 3.18 which is higher than the mean of average (3), indicates that not all the respondents know about these terminologies. These terminologies should be known by the engineers with respect to EVM; but these terminologies weren't known by many engineers which indicates again the weak of preparation of engineers in Yemen to use this technique in their monitoring and controlling the projects. In the first place, the mean of scale "Knowledge of EVM" is 3.30 which is slightly higher than the mean of average (3), refers to the respondents don't know the EVM perfectly, and maybe not all of them have studied EVM in bachelor program level. In developing countries, the engineers may not have been focused on this technique and they didn't discover their incapability to use it; because most of their projects which are small or large don't require EVM which leads to ignoring it and forgetting it. Knowledge of EVM hasn't found a ground to be established. In the light of the second scale "Applying EVM in monitoring and controlling process", the factor "Using traditional methods" had the mean' value of 4.72 , which is greater than the mean of average (3), indicates that the most of the respondents use the traditional methods to monitor and control their projects. This method is common in developing countries when there is no monitoring on the process of controlling the progress. Luck is the friend of the engineers in these countries otherwise the failure can be happened when the project maybe complex. Another factor which is "Using EVM" had the mean' value of 3.00, which is exactly the mean of average (3), referring to that the respondents may not use the EVM to monitor and control their projects because they didn't know it or they ignore using EVM due to the practices on the field. This affects definitely the monitoring and controlling the projects leading them towards failure. In Yemen, even the funded projects with foreign organizations haven't insisted on the EVM. This may be another reason to help avoiding using this technique. Also, the analysis shows the mean's value of 3.27 for the factor "preparing progress report with EVM", is slightly higher than the mean of average (3), which indicates that the most of respondents didn't write their projects' progress report with EVM, which leads to uncertainty and unreality. This confirms the pervious result which is there is no need or mandatory to use this technique.

Factor of "Determining cost variance with EVM" had the mean's value of 3.00, which is exactly the mean of average (3), means that the respondents didn't determine the cost variance with EVM and may be led to project failure. This issue was clear in a case study that was conducted by [4], determining the cost variance in early stage of execution which may be led to take a corrective action to avoid cost overrun. At the same time, the analysis shows that the factor of "Determining schedule variance with EVM" had the mean's value of 3.18, which is slightly higher than the mean of average (3), indicates that the respondents may not have knowledge about determining the schedule variance. This may not have been committing to use it according to the owner. Importantly, with respect to the factor "Determining Time Estimate at Completion by EVM", the analysis shows the mean's value of 3.27 , which is slightly higher than the mean of average (3), indicates that the respondents may not determine the time estimate at completion when their projects suffer from variance in schedule which considers one of the important report's progresses content. Equally important, the factor of "Determining Estimate at Completion by EVM" concerns about estimating cost at completion when the cost variance is exist. This factor had the mean's value of 3.54 which is slightly higher than the mean of average (3), refers to that the respondents haven't ability to estimate the cost at completion or they didn't use it, so they can't take a corrective action to treat this issues. This which also formulates the official report of project progress affects the reputation of the responsible contractor or consultant when it is not fitting. By the same token, the scale "Applying EVM in monitoring and controlling process" had the mean of 3.42, which is slightly higher than the mean average (3), indicates that the respondents didn't apply the EVM in the monitoring and controlling process which could be led to the failure of their projects. Moreover, they may not know how to use EMV. It can be seen this question is to measure the pervious questions in which confirm that this technique wasn't used in the construction projects mostly in Yemen. This result was contrary with the result got by Sutrisna, Pellicer [27] who proved that the EVM have used to improve the Spanish construction management. 


\section{Influences of Earned Value Management on Construction Project's Performance in Yemen}

Furthermore, theses results of this scale which appeared that EVM wasn't mostly used by Yemenis' engineers, another research proven that EVM used to predict the cost and time [3].

In like manner, the scale "Project performance", there were four factors belong to it. Factor of "Ability of monitoring and controlling" had the mean of 2.27, which is less than the mean average (3). It indicates that the respondents didn't concern about monitoring and controlling process, they managed their projects by unsystematic. Another factor "Projects' no delay" had the mean of 2.72, which is less than the mean average (3), confirms that the projects suffering delay because there was no systematic process of monitoring and controlling. As well, the analysis shows that the factor "No Cost overrun than planned cost" got the mean of 2.27, which is less than the mean average (3). It indicates that the most projects have suffered cost overrun from the monitoring and controlling point of view. In addition, the factor "Ability of determining increasing in cost and time" got the mean of 2.54, which is less than the mean average (3), also confirms that the systematic of monitoring and controlling process have been non-existent. As a matter of fact, the scale "Project performance" had the mean of 2.45 , which is less than the mean average (3), confirms the results of the previous two scales; obviously, the project performance was bad without systematic process of monitoring and controlling which assist the success.

It is clear that the EVM hasn't place in construction industry in Yemen; this problem has roots from the Bachelor program level in which the academics should be aware about. The EVM should be spread through engineers and practiced in the site, even if the projects are small scale which is confirmed by [3].

Three hypotheses should be verified to understand the relationships between the scales within the construction industry in Yemeni's society. SPSS IBM 19 used Pearson correlation test to verify the hypotheses as the following:

H1: Knowledge of EVM has a positive correlate with the monitoring and controlling process.

H2: Knowledge of EVM has a positive correlate with project performance.

H3: Applying monitoring and controlling process by EVM has a positive correlate with project performance.

It can be seen in table (9), the Pearson correlation for $\mathrm{H} 1$ is 0.86 value at level significant 0.01 , which indicates to reject the null hypothesis and accept the $\mathrm{H} 1$, as well, the relationship is positive which leads to conclude that there is a positive correlation with the monitoring and controlling process by knowledge of EVM. The second hypothesis had a value of 0.40 at level significant 0.01 , which indicates that $\mathrm{H} 2$ is accepted. The correlation is an intermediate and positive between the Knowledge of EVM and the project performance, which refers to the importance of Knowledge of EVM that may increase the correlation and effect value between them positively. The third hypothesis has a value of 0.51 at level significant 0.01 , which indicates that the hypothesis is accepted. Applying monitoring and controlling process has also a positive correlation with a project performance. These three hypotheses can be summarized in a theory as the following "if the knowledge of EVM is perfectly obtained in Bachelor program level and applied and practiced in site field of construction, it can be led to project's best performance". Developing countries don't apply the EVM in their projects ignoring its importance to success the projects, in Yemen as a developing country, the EVM doesn't spread as a culture between the engineers as a clear result from this study nor practiced in the field. Therefore, this study has showed the situation of EVM in Yemen, and encourages the academics to draw a plan in their positions to spread the EVM technique in Yemeni construction industry to avoid bad performance of their projects.

Table 9 Pearson correlation test

\begin{tabular}{|c|c|c|c|c|}
\hline \multicolumn{5}{|c|}{ Pearson Correlation } \\
\hline & & $\begin{array}{c}\text { Knowledge } \\
\text { of EVM }\end{array}$ & $\begin{array}{l}\text { Monitoring } \\
\text { and } \\
\text { controlling }\end{array}$ & $\begin{array}{c}\text { Project } \\
\text { performance }\end{array}$ \\
\hline \multirow{2}{*}{$\begin{array}{l}\text { Knowledge } \\
\text { of EVM }\end{array}$} & $\begin{array}{l}\text { Pearson } \\
\text { Correlation }\end{array}$ & 1 & $0.86^{* *}$ & $0.40 * *$ \\
\hline & Sig. (1-tailed) & & 0.00 & 0.00 \\
\hline \multirow{2}{*}{$\begin{array}{c}\text { Monitoring } \\
\text { and } \\
\text { controlling }\end{array}$} & $\begin{array}{c}\text { Pearson } \\
\text { Correlation }\end{array}$ & $0.86^{* *}$ & 1 & $0.51 * *$ \\
\hline & Sig. (1-tailed) & 0.00 & & 0.00 \\
\hline \multirow{2}{*}{$\begin{array}{c}\text { Project } \\
\text { performance }\end{array}$} & $\begin{array}{c}\text { Pearson } \\
\text { Correlation }\end{array}$ & $0.40 * *$ & $0.51 * *$ & 1 \\
\hline & Sig. (1-tailed) & \begin{tabular}{|l|}
0.00 \\
\end{tabular} & \begin{tabular}{|l|}
0.00 \\
\end{tabular} & \\
\hline
\end{tabular}

\section{CONCLUSION AND RECOMMENDATION}

The earned value management has ability to monitor and control the projects through the execution. It helps the engineers to avoid the losses in time and cost, as well as, helps them to forecast the variance in schedule and cost. It assists the engineers to prepare their progress reports systemically. Therefore, this study has investigated the situation of EVM in Yemen. Results showed that the EVM has not fully known or practiced by engineers. This led to bad performance for their projects. Furthermore, this study gives strong evidences of need to study and practice the EVM technique for Yemenis' engineers and academics in particular, and developing countries in general, in order to raise their performance even if the projects are small scales.

\section{REFERENCES}

1. Pewdum, W., T. Rujirayanyong, and V. Sooksatra, Forecasting final budget and duration of highway construction projects. Engineering, Construction and Architectural Management, 2009. 16(6): p. 544-557.

2. Ruiz-Fernández, J.P., et al., Influence of seasonal factors in the earned value of construction. Applied Mathematics and Nonlinear Sciences, 2019. 4(1): p. 21-34.

3. Avlijaš, R., G. Avlijaš, and M. Heleta, Application of Earned Value Based Metrics on Small-Scale Construction Projects/Primena Metode Ostvarene Vrednosti U Praćenju Manjih Gradevinskih Projekata. The European Journal of Applied Economics, 2015. 12(2): p. 1-8.

4. De Marco, A. and T. Narbaev, Earned value-based performance monitoring of facility construction projects. Journal of facilities Management, 2013. 11(1): p. 69-80.

5. Kwon, O.-c., et al., Application of Earned Value in the Korean Construction Industry - A Case Study. Journal of Asian Architecture and Building Engineering, 2008. 7(1): p. 69-76.

6. PMI, Practice Standard for Earned Value Management. 2014.

7. DoD, Earned value analysis system (EVAS) program analysis pamphlet (PAP). 2012, U.S. Department of Defense: Fort Lee, VA: Defense Contract Management Agency.

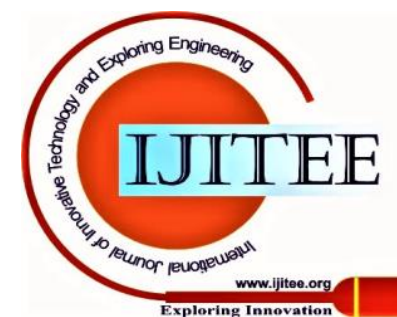


8. $\quad$ PMI, A guide to the project management body of knowledge. 2017, Newtown Square, PA: Project Management Institute.

9. APM, Earned value management : APM guidelines. 2008, Princes Risborough: Association for Project Management.

10. Ruskin, A.M., Two issues concerning the use of Earned Value Measurements. Engineering Management Journal, 2004. 16(3): p. 26-30.

11. Kauffmann, P., C. Keating, and C. Considine, Using earned value methods to substantiate change-of-scope claims. Engineering Management Journal, 2002. 14(1): p. 13-20.

12. Fleming, Q.W., Earned Value Project Management - Fourth Edition. 2016: Project Management Institute.

13. Eleyan, D. and N. El-Sawalhi, Project review in the project management: an investigation study on earned value and balanced scorecard. Journal of Statistics and Management Systems, 2010. 13(6): p. 1187-1209.

14. Cioffi, D.F., Completing projects according to plans: an earned-value improvement index. Journal of the Operational Research Society, 2006. 57(3): p. 290-295.

15. Fleming, Q.W. and J.M. Koppelman, What's your project's real price tag? harvard business review, 2003. 81(9): p. 20-20.

16. Cleland, D.I. and L.R. Ireland, Project management : strategic design and implementation. 2010, Boston: McGraw-Hill.

17. Ong, H.Y., C. Wang, and N. Zainon, Integrated earned value Gant chart (EV-Gantt) tool for project portfolio planning and monitoring optimization. Engineering Management Journal, 2016. 28(1): p. 39-53.

18. Yang, H., et al., A critical review of performance measurement in construction. Journal of Facilities Management, 2010. 8(4): p. 269-284.

19. Lipke, W., et al., Prediction of project outcome: The application of statistical methods to earned value management and earned schedule performance indexes. International journal of project management, 2009. 27(4): p. 400-407.

20. Acebes, F., et al., Beyond earned value management: A graphical framework for integrated cost, schedule and risk monitoring. Procedia-Social and Behavioral Sciences, 2013. 74: p. 181-189.

21. Abudayyeh, O. and W.J. Rasdorf, An assessment of cost and schedule control integration models. 1990, Tech. Rep. No. CE-90-10, Civ. Engrg. Dept., North Carolina State University ....

22. Latief, Y., G. Kusumaningtyas, and L. Supriadi. Work breakdown structure (WBS) dictionary development for the construction works of flyover projects. in IOP Conference Series: Earth and Environmental Science. 2018. IOP Publishing.

23. Brotherton, S.A., R.T. Fried, and E.S. Norman. Applying the work breakdown structure to the project management lifecycle. in PMI Global Congress Proceedings. 2008. Citeseer.

24. Naoum, S.G., Dissertation research and writing for construction students. 2007, Oxford: Butterworth-Heinemann.

25. Hair, J.F., et al., Multivariate data analysis. 2019

26. Ferketich, S., Focus on psychometrics. Aspects of item analysis. Research in nursing \& health, 1991. 14(2): p. 165-8.

27. Sutrisna, M., et al., Exploring earned value management in the Spanish construction industry as a pathway to competitive advantage. International Journal of Construction Management, 2020. 20(1): p. $1-12$

\section{AUTHORS PROFILE}

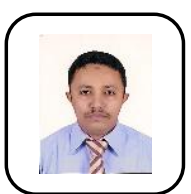

Waled Hakami is an assistant Professor at college of Engineering, Architecture Department in University of Science and Technology, Yemen. He received a PhD degree in 2017 and MSc in 2013 in Construction Management from Sudan University of Science \& Technology, Sudan. He teaches the Architecture and Construction Sciences for more than 6 years for undergraduate. As well, he has worked as site Engineer and consultant for many projects in Yemen and Sudan for 10 Years. His research interests concentrate on construction management, economics, and architecture.

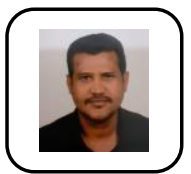

Mohammed A. Shameri is an assistant Professor at college of Engineering, Architecture Department in University of Science and Technology, Yemen. He received a PhD degree in 2015 from Malaysia and MSc in 2000 from University of Science and Technology, Yemen. He teaches the Architecture and Construction Sciences for more than 13 years for undergraduate and postgraduate. As well, he has worked as site Engineer and consultant for many projects in Yemen. His research interests concentrate on environment, solar energy, construction management, and architecture.

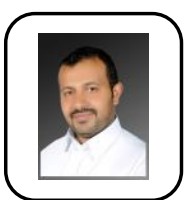

Belal R. Aldhubhani is the director of the consultancy and research engineering center (a specialized center in University of science and technology), assistant professor at the Department of Architecture Engineering UST, Yemen. Belal received his PhD from UST, Yemen in 2019 and MSc from UiTM University, Malaysia in 2009. His research focuses on planning projects, master plan and urban public policies. 